Roche Amplichip CYP450, now approved for use in both the USA and the European Union? An editorial in the $B M J$ (17 April 2007) provides a critical review of the evidence and concludes that the relationship between P450 genotype and antidepressant action is tenuous: there are just so many other metabolic and other factors that also influence drug concentrations.

In our thematic section in this issue, Pedro Ruiz summarises the variable response of broadly defined ethnic groups to psychopharmacological agents. Although he defines the role of the cytochrome P450 system as potentially relevant, we do not yet know exactly how important it is in relation to these well established differences. Edmond Pi and Weiguo Zhu discuss the relevance of genetic variants and their associated enzymes to the treatment of Far Eastern and Asian patients. Finally, Tarek Okasha emphasises the importance of other cultural influences which may interact with genetic vulnerability, such as support from families and the community, and the faith the patient places in the psychiatrist and in God.

\title{
The role of ethnicity in psychopharmacology
}

\author{
Pedro Ruiz MD
}

President of the American Psychiatric Association; Professor and Vice Chair of the Department of Psychiatry and Behavioral Sciences at the University of Texas Medical School at Houston, 1300 Moursund Street, Houston, Texas 77030, USA, email pedro.ruiz@uth.tmc.edu

- he association between ethnicity and pharmacology

has been reported in the medical literature for several decades. However, the relationship between ethnicity and psychopharmacology has become widely recognised only in the last two or three decades. The large-scale migration which started after the Second World War, at first to the USA and more recently to other higher-income countries, as a result of globalisation, has greatly contributed to the attention and focus given to these migrant groups. In this context, these migrant groups primarily comprise ethnic and racial minority groups. This article briefly reviews the relationship between ethnicity and psychopharmacological agents.

\section{The foundation}

The foundation of the relationship between ethnicity and psychopharmacology is based on three major principles (Ruiz, 2005):

O Pharmacogenetics. This mechanism focuses on the genetic and environmental factors that influence the functions of enzymes in the organism. Some of these enzymes act on psychopharmacological agents. Some persons are poor metabolisers and others are extensive metabolisers.

o Pharmacokinetics. This mechanism addresses the fate and distribution of pharmacological agents in the organism. It consists of four basic processes: absorption, distribution, biotransformation and excretion.

O Pharmacodynamics. This mechanism pertains to the interaction between receptors and pharmacological agents. The substances that bind with these receptors can be exogenous or endogenous.

Besides these three biological principles, we must also take into consideration non-biological factors, which can also influence the relationship between ethnicity and psychopharmacology (Pi \& Gray, 1998). These factors are all related to culture and include: diet, placebo effect, prescription patterns, stress, compliance factors, consumption of herbs, climatic effects, and so on.

Additionally, we must acknowledge the role of the cytochrome P450 enzymatic system in this regard (Ruiz, 2002). These enzymes are under genetic control, but certain isozymes can be induced by specific substrates, such as phenobarbital, ethanol and steroids. They can also be inhibited by certain drugs which are potent competitive inhibitors of these enzymes, such as cimetidine and ketoconazole (Pi \& Gray, 1998). The genetic polymorphism demonstrated by the CYP enzyme system leads to individuals being classified as extensive metabolisers or poor metabolisers. Table 1 shows which CYP subsystems primarily affect what types of psychopharmacological agent.

\section{Asian populations}

Of the different ethnic groups, the Asian populations are among the most studied with respect to ethno-psychopharmacological differences (Pi \& Gray, 1998). Studies have shown that Asian patients require lesser amounts of the following psychopharmacological agents than do the Caucasian population to achieve similar results: neuroleptics (haloperidol, clozapine), lithium and tricyclic antidepressants (clomipramine, desipramine).

Similarly, Asian populations have been shown to be more sensitive to psychopharmacological agents and, thus, to have more severe side-effects than Caucasian populations. This is another confirmation that Asian populations need lower dosages of psychopharmacological agents than the Caucasian population. 
Table 1 Effects of four main CYP subsystems on psychopharmacological agents

\begin{tabular}{|c|c|}
\hline $\begin{array}{l}\text { Cytochrome } \\
\text { subsystem }\end{array}$ & $\begin{array}{l}\text { Psychopharmacological agents primarily } \\
\text { affected }\end{array}$ \\
\hline P450 2D6 & $\begin{array}{l}\text { Antipsychotics (both typical and atypical) } \\
\text { Tricyclic antidepressants } \\
\text { Selective serotonin reuptake inhibitor } \\
\text { antidepressants } \\
\text { Agents such as amphetamines, propranolol } \\
\text { and venlafaxine }\end{array}$ \\
\hline P450 2C19 & $\begin{array}{l}\text { Benzodiazepines } \\
\text { The tricyclic antidepressants clomipramine and } \\
\text { imipramine } \\
\text { The selective serotonin reuptake inhibitor } \\
\text { citalopram } \\
\text { Agents such as propranolol }\end{array}$ \\
\hline P450 3A4 & $\begin{array}{l}\text { Some antidepressants such as nefazodone, } \\
\text { sertraline and venlafaxine } \\
\text { Sedative hypnotics such as cloprazolam, } \\
\text { clonazepam, diazepam, midazolan, triazolan } \\
\text { and zolpidem } \\
\text { Agents such as carbamazepine and codeine }\end{array}$ \\
\hline P450 1A2 & $\begin{array}{l}\text { The antipsychotic clozapine } \\
\text { Tricyclic antidepressants such as amitriptyline, } \\
\text { imipramine and maprotiline } \\
\text { Agents such as caffeine, propranolol and } \\
\text { tacine }\end{array}$ \\
\hline
\end{tabular}

\section{African/Black populations}

Contrary to general beliefs that African/Black populations require higher doses of psychopharmacological agents than the Caucasian population for the treatment of most psychiatric disorders, recent studies have shown that this is not the case. These studies (Varner et al, 1998, 2000; Ruiz et al, 1999) have shown that African/Black populations require smaller doses of tricyclic antidepressants (desipramine, imipramine and nortriptyline) than the Caucasian population for the treatment of major depression and, similarly, smaller doses of selective serotonin reuptake inhibitors (fluoxetine and sertraline).

African/Black populations do require equal amounts of typical neuroleptic agents to the Caucasian population for the treatment of schizophrenia. With respect to atypical neuroleptics, African/Black patients require higher doses of clozapine than Caucasian patients for the treatment of schizophrenia. They also require larger amounts of olanzapine but equal doses of risperidone (again in comparison with Caucasian patients).

\section{Hispanic populations}

With respect to Hispanic populations, recent studies have shown that they need smaller amounts of typical neuroleptics than the Caucasian population for the treatment of schizophrenia. Likewise, they require smaller amounts of certain atypical neuroleptics (e.g. risperidone) than Caucasian populations.

It is also well accepted that Hispanic people require smaller doses of tricyclic antidepressants and that they complain more about the side-effects of tricyclic antidepressants than the Caucasian population. There is also evidence that they somatise more than the Caucasian population (Pi \& Gray, 1998).

\section{Conclusion}

During the last two or three decades, much attention has been given to the field of cross-cultural psychiatry. Similarly, much attention has been focused on the clinical needs of ethnic minority populations, given the current high rates of migration to higher-income countries. Additionally, globalisation has led to research priorities being given to the psychiatric needs of multi-ethnic groups. All this has led to research advances in the area of ethno-psychopharmacology. These efforts should result in treatment benefits to ethnic and racial groups who were ignored or not given enough attention in the past. Obviously, additional research efforts are needed in this line of investigation.

\section{References}

Pi, E. H. \& Gray, G. E. (1998) A cross-cultural perspective on psychopharmacology. Essential Psychopharmacology, 2, 233-262.

Ruiz, P. (2002) Ethnic consideration in the psychopharmacology treatment of patients with schizophrenia. Mental Health Outcomes, December, 7-8

Ruiz, P. (2005) Ethnopsychopharmacology: recent research advances. Psychiatriki, 16, 132-134

Ruiz, P., Varner, R. V., Small, D. R., et al (1999) Ethnic differences in the neuroleptic treatment of schizophrenia. Psychiatric Quarterly, 70, 163-172.

Varner, R. V., Ruiz, P. \& Small, D. R. (1998) Black and white patients response to antidepressant treatment for major depression. Psychiatric Quarterly, 69, 117-125

Varner, R. V., Ruiz, P. \& Small, D. R. (2000) Ethnopsychopharmacology in the public sector. In Ethnicity and Psychopharmacology (ed. P. Ruiz), pp. 115-129. American Psychiatric Press.

\section{College Volunteers Programme}

Have you ever wondered how you could contribute to the development of low-income countries? Do you think your skills and professional experience can be of use to medical organisations and colleagues around the world? As a College volunteer you will have the opportunity to make a practical difference, as well as to learn new skills and to gain further professional and personal experience.

The College Volunteers Programme has been established as a service to our international members seeking expertise to help them develop services in their own countries, and to UK members wishing to utilise their professional expertise in a meaningful and exciting way. The scheme is open to senior members and fellows of the College and to senior trainees who are looking to offer their skill, knowledge and expertise in exchange for international experience, broadened horizons and an enhanced view of international psychiatry offered by lowand middle-income countries.

If you wish to register as a volunteer please contact the College International Unit or download the registration form from our website http://www.rcpsych.ac.uk/college/boardofinternationalaffairs/seniorvolunteersprogramme.aspx 